\title{
DIE OPENBARINGSLEER VAN SCHILDER
}

\author{
A.L.A. Buys ${ }^{1} \&$ S.A. Strauss ${ }^{2}$ \\ ABSTRACT \\ SCHILDER'S DOCTRINE OF REVELATION
}

\begin{abstract}
Although Schilder's theology was almost exclusively known in the Netherlands, its significance is not restricted to that country. In principle Schilder based his theology on revelation in Scriptures. According to Schilder, revelation may be described as God's disclosing of the truth from heaven to people on earth in Jesus Christ. This revelation is embodied in various dispensations but always remains anthropomorphic, due to the love of God, which culminates in the Word becoming flesh. Two fundamental axioms of Schilder's theology, namely the unity of Scriptures and the unity of the church can be derived from his firm belief in the unity of God. Schilder's view on revelation is still relevant, because it provides an effective answer to both mysticism and fundamentalism.
\end{abstract}

Die Nederlandse gereformeerde dogmatikus Klaas Schilder ${ }^{3}$ was geen sistematiese teoloog nie. Daarvoor was hy 'n te woelige en betrokke gees - iemand wat eerder sy insigte deur polemiese aktualiteit as deur die formele loci-metode deurgegee het. Tog beteken dit nie dat Schilder se teologiese denke ongeorden was nie. Schilder se hele teologie vertoon 'n goeie koherensie wat berus op sekere grondgedagtes. ${ }^{4}$ Hierdie grondgedagtes is vir hom altyd geopenbaarde beginsels. Grondgedagtes is dus nie 'n versameling stelreëls ${ }^{5}$ nie.

1 Dr. A.L.A. Buys, Predikant Gereformeerde Kerk Pietersburg-Noord, Posbus 88, Pietersburg, 0700. Gepromoveer in: Departement Dogmatologie, Fakulteit Teologie, Universiteit van die Vrystaat, Posbus 339, Bloemfontein, 9300. alabuys@lantic.net

2 Prof. S.A Strauss, Departement Dogmatologie, Fakulteit Teologie, Universiteit van die Vrystaat, Posbus 339, Bloemfontein.

strausssa.hum@mail.uovs.ac.za

$3 \quad 1890-1952$.

4 Hierdie grondgedagtes is vir Schilder skriftuurlike grondgegewens, of beginsels, van waaruit redenering begin.

5 Volgens Schilder:

De kerk toch gaat niet uit van beginselen, doch van de openbaring der beginselen. Gods openbaring in de Schriften nu — immers, daarmee heeft de kerk te doen - heeft wel beginselen aangegeven, men kan ze ook wel er uit afleiden; maar ze liggen nooit "gereed", nooit "uitgewerkt", 
Hierdie grondgedagtes moet inderdaad niks anders wees nie as 'n deurgee van die openbaring, anders vorder 'n mens niks verder as kerklike selfhandhawing nie.

In sy openbaringsleer wil Schilder enduit gereformeerd dink. Hy handhaaf dus vanuit die gereformeerde belydenis die twee modi waardeur God geken kan word: die Skrif en die skepping. Hy erken ook die inspirasie van die Heilige Gees en vermy enige vergeesteliking ${ }^{6}$ van die Skrif. Ook behou hy die tradisioneel gereformeerde onderskeid ${ }^{7}$ tussen die normatiewe en historiese Skrifgesag.

Schilder verwerp ook enige gedagte van 'n theologia naturalis. Dit is vir hom baie belangrik om te bely dat God nie op empiriese ${ }^{8}$ wyse geken kan word nie. Schilder se kenteorie maak ruimskoots plek vir geloof. Hy wil geensins die goddelike aandeel in die Skrif probeer bewys nie, en verwerp dus die teodisee. ${ }^{?}$

\section{VAN BO NA ONDER}

Aangesien Schilder die oorsprong van die openbaring by God in die hemel self vind, wys hy enige evolusionistiese begronding van die openbaringsleer af. Hy is baie allergies vir enige vorm van subjektivisme aangaande die openbaring. Die menslike gevoelslewe is beslis vir hom ingebind deur die openba-

nooit "geformuleerd" in de openbaring "gegeven". Teruggang naar een beginsel betekent in de kerk — zal het goed zijn — altijd teruggang naar het Woord. Anders is het geen reformatie, doch ten principale zelfhandhaving (Verzamelde Werken Kerk II, 1962:81).

6 Vgl. Om Woord en kerk III (1951:46).

7 "De gereformeerden hebben steeds onderscheiden tusschen normatief én bistorisch Schriftgezag." Daarvolgens was byvoorbeeld Lukas wel geïnspireerd toe hy Stefanus se rede weergee, maar Stefanus nie toe hy dit uitspreek $(\mathrm{Om}$ Woord en kerk III 1951:88).

8 Volgens Schilder:

Op empirische wijze kán God niet worden gekend. De eeuwige kan slechts op geestelijke wijze worden aanschouwd. En de geestelijke aanschouwing is juist het geloof (Om Woord en kerk III 1951:9).

9 Volgens Schilder:

Wie de onmogelijkheid der theodicee heeft erkend, zal ook afzien van alle pogen om met argumenten, aan den uitwendigen schijn der dingen, het innerlijke wezen der Schrift te rechtvaardigen (Om Woord en kerk III 1951:95). 
ring, Schilder kan dan ook nie genoeg waarsku teen die gevaar wat mistiek ${ }^{10}$ vir die Christendom inhou nie. Hy sien dit as niks anders nie as 'n verwerping en vervanging van die goddelike openbaring.

Vir Schilder is die openbaringleer se kern altyd dat dit 'n openbaring van bo na onder is. Van God af na die mens toe. God spreek vanuit die hemel in Christus $^{11}$ die waarheid. Die goddelike openbaring is gerig op die hele mensdom op aarde en nie in die eerste plek net op die kerk nie. Schilder wil egter nie toegee dat die handhawing van die vertikale lyn in die openbaring noodwendig 'n uitsluiting ${ }^{12}$ of onderwaardering van die horisontale inhou

10 Schilder onderskei tussen gesonde mistiek as geloofsfunksie en afwykende mistiek. By eersgenoemde kom nooit 'n devaluering of skeiding van die Woord óf die Gees voor nie, terwyl afwykende mistiek die openbaring afhanklik maak van die menslike gevoelslewe:

En daarom kan reeds dit samen-opkomen van Logos en Pneuma in de objectieve heilsopenbaring van God voor de ware mystiek nooit anders zijn dan een scherp gebod. Om wat God één gemaakt heeft, niet te scheiden (Tusschen 'ja' en 'neen' 1929:214).

De gezonde mystiek wil het geopenbaarde (en dus kenbaar gemaakte) beleven. Daarom wil zij tusschen "kennen" en "beleven" geen scheiding zien gemaakt, ook maar geen oogenblik. De daad van het kennen, den wil tot kennen rekent zij zelfs tot de onmisbare acten en ontplooiingen van het leven. Maar de tot afwijking neigende mystiek speelt het "kennen" het "beleven" uit, en makt hier een onderscheiding, die straks tot scheiding wordt (Tusschen 'ja' en 'neen' (1929:203).

11 Volgens Schilder:

Want Christus is wel van boven en de waarheid ook en de openbaring. Maar de kerk is nog beneden. Ze gaat wel naar boven, vanwaar ook haar leven en haar roeping is. Maar zij is nog beneden; zij is in het platte vlak van haar woestijn (Om Woord en kerk IV 1953:94).

12 Schilder verwerp 'n valse akkommodasiegedagte, waar die vertikale bloot onherkenbaar by die horisontale akkommodasie vind. Verder wys hy daarop dat die horisontale nie 'n growwe verbreking van wat reeds in die geskiedenis ontstaan het, sou impliseer nie. Laasgenoemde is ook sy groot beswaar teen die openbaringsleer van Barth. In sy proefskrif werk Schilder hierdie punt verder uit. Hy kontrasteer Calvyn en Barth op hierdie punt:

Grundlegend für Calvins Gedankenschema ist dabei die Ueberzeugung, dass Gott "Ein" ist. Seine Virtutes sind nicht voneinander zu trennen. Deshalb ist der Deus loquens mit dem Deus creator eins, sobald es sich nämlich auf das Reden Gottes nicht in der Trinität, sondern auf das Reden ad extra bezieht, das Reden als opus exeuns. Dieses loqui Gottes ist creare, und sein creare loqui. "Das Wort Gottes ist Antwort, sagte K. Barth. Das Wort Gottes kreiert Frager und Frage, meint Calvin." (Schilder 1933:419-420). 
nie. Hy vind geen teenstelling ${ }^{13}$ daarin nie, en deur die inwoning van God wil Hy almeer die vertikale oorwinnend laat inwerk op die horisontale. Vir Schilder bestaan daar nie so iets soos 'n saamgestelde "onderste-bo" openbaring nie.

\section{MENSLIKE BEGRIPSVERMOË}

Maar alhoewel die openbaring altyd van bo na onder kom, pas God tog sy openbaring aan by die begripsvermoë van die mens. Schilder stel dat die openbaring nooit paradoksaal, in die strengste sin van die woord, kan wees nie. Vir Schilder dikteer die openbaring die groot tema van God in die wêreld. Dit is wel so dat in die daaropvolgende uitwerking van die tema God, as gevolg van die mens se bevattingsvermoë, die aksent in verskillende tye op verskillende aspekte van die waarheid laat val. Maar hierdie aksentverlegging weerspreek ${ }^{14}$ nooit die tema, of gedeeltelik, of in sy geheel nie.

Die kenmerkend ${ }^{15}$ tipiese van die Christendom is vir Schilder dat die mens teenoor God as swak en klein gesien word. Vir sy suiwer openbaring maak God gebruik van menslike aanknopingspunte, Hy vind aanvanklik aansluiting by die menslike, onsuiwer denkbeelde. Dit beskryf Schilder as

13 Volgens Schilder:

Hij hoort de openbaring verkondigen, dat het "horizontale vlak" en het "vertikale" geen tegenstellingen mogen blijven, omdat God ze tot elkaar brengen wil; hoe verder God met de wereld Zijn doel naderbij komt, des te meer wil Hij woning maken bij de menschen, en Zijn Logos in ons leven doen overwinnen. De leugen brekende, en afkondigende de waarheid (Bij dichters en schriftegeleerden 1927:136).

14 Volgens Schilder:

En de daarna volgende uitwerking van dat thema is wel zoo, dat God, naar dat de menschen het bevatten kunnen, in den eenen tijd het accent meer laat vallen op deze, in een anderen tijd meer op een andere waarheid, doch daar moet dan weer aanstonds aan toegevoegd worden, dat deze accentverlegging niet den zin, niet het thema, of ook maar een van zijn deelen tegenspreekt; zoodat de Bijbel niet para-doxaal (in den strengeren zin) kan zijn, noch in zijn geheel, noch in zijn deelen (Bij dichters en schriftgeleerden 1927:137).

15 Volgens Schilder

...dat de mensch zwak is en klein tegenover God, dat is ten slotte het kenmerkend-typische in de christelijke religie tegenover elke andere beschouwing (Om Woord en kerk I 1948:135). 
God se liefdeslis, ${ }^{16}$ waar God uit die menslike woordeboek ook sy woorde kies. Daarvoor moet God gedank word. Dit is vir Schilder baie belangrik dat nie by hierdie aanknopingspunt stilgestaan word nie, maar dat openbaring van God deur sy Seun altyd voor oë gehou moet word. Die lokkende in die aansluitende ${ }^{17}$ element van die openbaring moet nooit losgemaak word van die leidende in die Woord nie.

In aansluiting by Calvyn ${ }^{18}$ en Bavinck beskou Schilder alle ${ }^{19}$ openbaring as antropomorfisme. Die antropomorfisme ${ }^{20}$ verbind Schilder direk aan Christus se profetiese amp en sy menswording. God se liefde is juis hierin geleë dat Hy die mens in sy eie taal aanspreek. Die antropomorfisme is 'n daad van God self. Schilder betrek die tweede gebod ${ }^{21}$ hierby, waar die mens ver-

16 Volgens Schilder:

Ach, ook uit ons woordenboek moet God de woorden kiezen. Ook bij ons dwalende begrippen sluit aanvankelijk de Heere zich aan, ook in onze onzuivere denkbeelden legt $\mathrm{Hij}$ door de openbaring van het teeken Zijns Zoons de eerste aanknopingspunten voor zijn zuivere waarheid. Dat is de list der liefde; en wij danken Hem daarvoor. Maar wij mogen daarbij niet blijven staan. De list staat nog maar aan het begin van den liefdeweg. Het moet ook bij ons van de list tot de klare betuiging der liefde, het moet ook bij ons van de ster naar het Woord, van het lokken naar het leiden; het moet altijd van Gods Woord in de natuur tot Gods Woord in de Schrift $(\mathrm{Om}$ Woord en kerk I 1948:2; Vgl. ook Verzamelde werken. Kerk II 1962:31, Heidelbergsche Catechismus I 1947:111.)

17 Volgens Schilder:

...Christus heeft zijn eschatologische redenen, hoewel ze tot het einde aller dagen reiken, vasgekoppeld aan het zintuigelijk-waarneembaar, feitelijk gebeuren van den naasten tijd, waarin Hij sprak $(\mathrm{Om}$ Woord en kerk IV 1953:67).

18 Vgl. De Jong (1995:119) waar aangetoon word dat beide Calvyn en Schilder die akkommodasiegedagte nie los maak van die verligting van die Heilige Gees nie.

19 Volgens Schilder:

Laat mij volstaan met enkele woorden van Dr. H.Bavinck: "Alle openbaring is anthropomosphisme, is een zekere menschwording Gods"

(Bij dichters en schriftgeleerden 1927:395).

20 Vgl. Om Woord en kerk III (1951:115).

21 Volgens Schilder:

Het tweede gebod verbiedt ons een beeld van God te maken. Te MAKEN. Toch heeft God Zelf van Zich in beeldvorm gesproken. Toch is de wereld, en daarin de schepselen, groot en klein, een boek met 'letteren', waaruit van Hem te lezen valt... Kortom: God maakt de beelden wel... Zoo is dit tweede gebod een bewijs hiervan, dat het 
bied word om beelde van God te maak. Dit is egter geheel iets anders as God self in beeldvorms Homself openbaar. Schilder onderskei skerp tussen die suiwer openbaring wat God gee, waarmee die mens langs die weg van antropomorfe denke omgaan aan die een kant, en aan die ander kant of die mens antropomorfe voorstellings van God maak, los van die openbaring. Die een is 'n genadeweldaad van God, die ander is sonde teen die openbaring.

God verblind ${ }^{22}$ of hipnotiseer ${ }^{23}$ die mens nie met die lig van sy openbaring nie. Die mens word gevoed met die openbaringslig, maar nie meer as wat vir ons moontlik is om te dra nie. Van geweldsoorrompeling is daar geen sprake nie. Terwyl die openbaring bevatlik na die mens toe kom, beteken dit aan die ander kant ook weer nie dat die openbaring uitputlik is nie. Daar is vir Schilder ' $n$ verdiepende ${ }^{24}$ voortgang. Die intensiteit van die openbaring is dus van so 'n aard dat die openbaring tegelykertyd ook 'n bedekking ${ }^{25}$ is.

verschil maakt, of God Zelf ons Zijn zuivere openbaring GEEFT, om daardoor, ook langs den weg van het antropomorphe denken, onzen geest werkzaam te zetten, dan wel, of wij zelf onze voorstellingen maken, los van zijn openbaring, geheel, of ook voor een gedeelte, uit eigen ziel. Het eerste is een weldaad, een zegen, een genade; het tweede is een zonde, waartegen het gebod zich verheft (Bij dichters en schriftgeleerden 1927:398-399).

22 Vgl. Om Woord en kerk I (1948:57).

23 Volgens Schilder:

...maar God wil geen openbaring geven, die den mensch als't ware onder hypnose brengt en hem in dien zin overweldig $(\mathrm{Om}$ Woord en kerk III 1951:11).

24 Volgens Schilder:

Maar de onuitputtelijkheid van het teeken komt u herinneren, dat heden Gods zelfopenbaring haar voltooiing begint; dat ge nu zijt in de laaste bedeeling der tijden, dus de diepten Gods $\mathrm{u}$ al dieper en hetgeen van Hem doorzocht moet worden u al ondoorzoekelijker wordt (Om Woord en kerk I 1948:57).

25 Volgens Schilder:

Zijn licht is ook te machtig voor onze sterfelijke oogen en ooren. En God Zelf weet dat. Ja, nog meer, God Zelf rekent daarmee. Hij richt Zelf heel zijn openbaring daarnaar in. Hij bedekt Zich immer. Elke openbaring is tegelijk bedekking van Zijn licht, tempering van $\mathrm{Zijn}$ gloed. Altijd kiest God een middelaar: Mozes, een engel, den Verbondsengel, Christus. Heel de Schrift is een voortdurende afbuiging naar onze menschelijkheid; overal gaat ze uit van de gedachte, dat Gods spreken zijn geweldigheid en volstrektheid moet inperken, opdat wij het zouden kunnen verdragen $(\mathrm{Om}$ Woord en kerk I 1948:99; vgl. ook Schilder 1926:255-277 vir sy eksegese van Gen. 15:12,17). 
Die feit dat die openbaring bemiddel word, relativeer ${ }^{26}$ die openbaring op geen enkele manier nie. Schilder wil dus 'n ontwikkelingslyn raaksien in die openbaringsaansluiting van God by die menslike manier van verstaan.

Dit het vir hom te doen met die ontwikkeling vanaf' $n$ laer geestelike ${ }^{27}$ ontwikkelingsvlak na een wat op 'n hoër geestelike niveau opereer. Die openbaring aan Israel is sigbaar op die aarde ingestel op die menslike liggaamlike oog, om die spreke van God uit die hemel te verduidelik vir die geestelike oog. Hierdie ontwikkelingslyn het baie te doen met verskillende openbaringsplekke in die verskillende openbaringsbedelings. Hierdie aansluiting by die menslike begripsvermoë het 'n groot invloed op Schilder se siening oor die ooreenkomste en verskille tussen die Ou en die Nuwe Testament. Hy aksentueer die hemel-aarde onderskeiding baie skerp.

\section{VERSKUIWING VAN DIE KERNPUNT}

Schilder sien 'n verskuiwing in die kernpunt van die openbaringsheerlikheid vanaf die aarde in die Ou Testament, na die hemel in die Nuwe Testament. $\mathrm{Na}$ die hemelvaart van Christus en die uitstorting van die Heilige Gees is die kernpunt van God se openbaringsspreke verskuif ${ }^{28}$ na die hemel. Wel kom God se spreke nog tot die aarde deur die Heilige Gees, maar Jesus Christus spreek uit die hemel. In dié sin praat Schilder dan van die open-

26 Vgl. Berkouwer (1989:242-243). Hy toon aan dat Schilder die woord "indirek" met betrekking tot die openbaring afwys as 'n relativering wat uit die dialektiese teologie se woordeskat kom.

27 Vgl. Om Woord en kerk I (1948:103).

28 Volgens Schilder:

Dit is toch het groote onderscheid: tot Israel God Zijn sprake op aarde, maar nu spreekt Hij, God, ons toe uit de hemelen. Nu geeft God goddelijke antwoorden uit den hemelen! Tot Israel kwamen de Godswoorden op aarde. De aarde, het zichtbare, "deze berg Sinai", was het kernpunt der openbaringsheerlijkheid van God. En daarom kunnen ook later de Levieten zingen: Gij Zijt nedergedaald op den berg Sinai en hebt met hen gesproken! (Neh. 9:13). Dat is het: nedergedaald is God. De aarde was toen plaats Zijner geweldige lichtopenbaring en sterkte-daad. Maar dit is de glorie van het Nieuwe Testament, telijk het na Christus' hemelvaart en de uitstorting van den Pinkstergeest zich vervult; nu is de kernpunt van Gods openbaringspraak, van de energiedaad der genade, van de bediening der genade en der verzoening, verlegd naar den hemel. Wel komt Gods spreken tot de aarde, het komt door den Geest. Maar onze Profeet — in den hemel is hij (Om Woord en kerk I 1948:103; Schilder sê dit in 'n preek oor Heb. 12:25 "...nou dat Hy uit die hemele spreek.") 
baringsadres. Dit het hoofsaaklik in die Ou Testament gekulmineer in die volk Israel as openbaringsvolk en die Jerusalems $\mathrm{e}^{29}$ tempel as openbaringsplek. In dié verband stel Schilder ook sy beskuldiging dat sektes wat wil terugkeer na vorige openbaringsbedelings, in die slaggat trap dat vorige openbaringsarmoede ${ }^{30}$ verheerlik word as rykdom. In dié sin praat Schilder van die Pinksterarmoede, waar die kern van die werking van die Gees deurgegee word, maar wat geensins die somtotaal daarvan verteenwoordig nie.

\section{GELOWIGE ONTVANGS VAN OPENBARING}

Daarom sê Schilder dat die hermeneutiese en kenteoretiese aspekte nie meer plekmatig ${ }^{31}$ bepaal word nie, maar deur 'n kennende geloofsluisteringesteldheid. Die geloof ${ }^{32}$ speel 'n belangrike rol by Schilder se openbaringsleer. Daardeur word die openbaring ontvang. Hy onderskei regdeur sy teologiese werk tussen Skepper en skepsel, tussen die sprekende ${ }^{33}$ God en die horende mens. Die geloof stel nie die openbaring saam nie, maar deur die geloof word die openbaring aanvaar. ${ }^{34}$ Hierin erken Schilder ook die werking van die Heilige Gees. Nie net in die teopneustiese ${ }^{35}$ sin nie, maar pneumatieschristologies deurdat die Gees geloof skenk en daardeur lewe aan die kerk skenk. Die noodsaak van die geloof by die openbaring is vir hom daarin geleë dat die openbaring altyd primêr bly, maar dat sonder geloof die openbaring nie lewend aktueel vir die mens is nie.

29 Vgl. Om Woord en kerk I (1948:111).

30 "Dat moge armoede, achteruitgang, schijnen, het IS toch rijkdom, vooruitgang." (Om Woord en kerk I 1948:103).

31 Volgens Schilder: ....antwoord op de vraag, hoeveel, en hoe fel, en hoe zuiver ik ken, hangt niet af van de vraag: waar woon ik, doch van de andere: wat hoor ik? (Verzamelde werken: Kerk III 1965:426).

32 Volgens Schilder:

Zonder geloof is Gods openbaring zoo al niet dood, dan toch niet levend in dien zin dat ze ons het leven schenkt (Om Woord en kerk III 1951:11).

$33 \mathrm{Vgl}$. Bij dichters en schriftgeleerden (1927:116).

$34 \mathrm{Vgl}$. Bij dichters en schriftgeleerden (1927:358).

35 Schilder handhaaf die gereformeerde organiese inspirasieleer, wat hy deurtrek tot by die vasstelling van die kanon. Vgl. Bij dichters en schriftgeleerden (1927:358). 
Dit is van uiterste belang dat Schilder sien dat daar geen bewys ${ }^{36}$ vir die waarheid van die openbaring kan wees nie. Die implikasie hiervan is dat hy nooit werk met die sogenaamde absolute waarheid nie, aangesien dit juis die hele openbaringsgedagte sou kanselleer. Dit bring nie alles op losse skroewe nie, maar handhaaf juis die waarheid sonder om enige eksterne bewys (soos verraai in die byvoeglike naamwoord absoluut) aan die waarheid te wil koppel. Die openbaring moet juis as goddelike openbaring in die geloof ontvang word. Hierdie geloofstoenadering moet onderskei ${ }^{37}$ word van 'n blote opsoek van God. Daarom maak hy die stelling dat God nooit die sekerheid van die realiteit van sy beloftes skenk, alvorens $H y$ nie eers geloof ${ }^{38}$ eis nie.

\section{LIEFDE EN HAAT}

Een van Schilder se grondgedagtes ${ }^{39}$ met betrekking tot die openbaring is dié van liefde en haat. God openbaar die heilsgeskiedenis ${ }^{40}$ deur die openbaringsgeskiedenis uit liefde vir die wat die heil moet beërf. In liefde soek die openbaring van God aansluiting by die klein menslike verstaansvermoë, maar die mens mag weer van sy kant af nie hierdie liefde onbeantwoord laat deur 'n gerieflike gemaksone ten opsigte van die openbaring te bepleit nie. Dit vereis opofferende liefde om aan God se openbaringsfeesmaal aan te sit, aangesien dit vereis word dat ons ons gewone beordeling ${ }^{41}$ van dinge prysgee.

Die liefde van God in die openbaringslig kan ook by die ontvangkant $\operatorname{verag}^{42}$ word deur eklektisisme en subjektivisme. Subjektivisme lei nood-

36 Volgens Schilder:

...kunnen wij het onderscheid tusschen apokriefe en kanonieke berichtgeving ook bewijzen? Ons antwoord is: neen. Gods waarheid, indien ze geopenbaard is, kan nooit bewijsbaar zijn, zoomin als Hij zelf het is (Bij dichters en schriftgeleerden 1927:368).

37 Vgl. Om Woord en kerk III (1951:17).

38 Vgl. Om Woord en kerk III (1951:21).

39 Vgl. Om Woord en kerk I (1948:37, 102).

40 Vgl Verzamelde werken: Kerk II (1962:163) en sy Heidelbersche Catechismus II (1949:262-263) vir Schilder se onderskeid tussen heilsgeskiedenis en openbaringsgeskiedenis.

41 Vgl. Bij dichters en schriftgeleerden (1927:368).

42 Vgl. Om Woord en kerk I (1948:99), Christus aan den ingang van Zijn lijden I (1977:138) 
wendig tot eklektisisme waar die klaarblyklikheid ${ }^{43}$ van die Skrifopenbaring weer in gedrang kom. Daarmee saam moet onthou word dat Schilder geen graduele ${ }^{44}$ omgang met die waarheid ken nie. Die geopenbaarde waarheid is altyd van belang juis vanweë die feit dat die waarheid hierdie staanplek self opeis.

'n Magtige wapen in Schilder se hand teen subjektivistiese omgang met die openbaring is die eenheid ${ }^{45}$ van die openbaring - iets wat hy voorop stel. Die geheel het voorrang ${ }^{46}$ bo die dele; dit is ook 'n grondgedagte van Schilder. Dit is uiters belangrik om te onthou dat Schilder hierdie eenheidsgrondgedagte direk begrond op die eenheid ${ }^{47}$ van God. ${ }^{48}$

Hier is Schilder ' $n$ wagter op die muur en waak hy teen spiritualisme, ${ }^{49}$ waar subjektivisme verbloem en verdedig word deur die beroep op 'n innerlike lig. Schilder wil die belydenis dat die Heilige Gees altyd deur alle waarheid leiding wil gee, maar nooit buite die Woord om nie, handhaaf.

43 Schilder rig sy kritiek teen Barth veral teen die paradoksgedagte:

Zonder de "klaarblijkelijkheid" kan de gereformeerde nu eenmaal niet leven. Wie er op scheldt, is als wie de moedersmelk ridiculiseert, die hem toch maar ' $n$ fermen kerel maakte. Bestaat de klaarblijkelijkheid in de openbaring niet, is ze een dwaze of pendante fictie, dan komt onze exegese zelfs niet aan den gang, en ons geloof niet en onze theologie niet (Bij Dichters en Schriftgeleerden 1927:134-135).

...men moet de "klaarblijkelijkheid" in de openbaring niet belachen. Wat de klaarblijkelijkheid beteekent voor de schriftgeworden Woord, dat is vervuld in het Vleeschgeworden Woord. Dit nu heeft onder ons niet geflikkerd, doch gewoond; het heeft een katheder en ons God geexegetiseerd (Bij dicbters en schriftgeleerden 1927:147).

44 Volgens Schilder:

Maar, zoo vragen wij, wat zijn hoofdwaarheden en wat zijn "waarheden" van minder belang? Is niet de waarheid altijd belangrijk? Juist, omdat ze waarheid is en wáárheid wil genaamd worden? $(\mathrm{Om}$ Woord en kerk III 1951:39).

45 "Eerst de eenheid der openbaring, dan die van de openbaringswoorden" ( $\mathrm{Om}$ Woord en kerk III 1951:95).

46 Vgl. Tusschen 'ja' en 'neen' (1929:188;192-201).

47 Vgl. Om Woord en kerk III (1951:59).

48 Volgens Schilder:

... dat God een is en dat daarom Zijn toorn een is, en Zijn komen een. Al Zijn komen is een komst. Al Zijn dagen zijn een dag. Al zijn oordelen een gericht. Daar is eenheid in de geschiedenis, want Gods plan is er in; en daarom schrijdt het alles voort tot het eene doel, dat alle dingen naderkomt (Om Woord en kerk I 1948:72).

49 Vgl. Om Woord en kerk III (1951:57). 
Om te weet of die Heilige Gees getuienis lewer, moet daar gevra word na ooreenstemming met die Skrif. Waar dit nie gebeur nie, tree verwarring in deurdat die mens God een dag dank vir 'n openbaring en die volgende dag dieselfde openbaring as ou vodde afkeur.

\section{EWEWIG EN KERN}

Schilder lê verder 'n noue verband tussen geloofsinhoud ${ }^{50}$ en openbaringsinhoud, in die sin dat geloofsinhoud erken moet word as openbaringsinhoud. Indien dit nie die geval is nie, verval die aanspraak op geloof en word dit slegs eiesinnigheid. Teenoor die eklektisisme wil Schilder 'n ewewigtigheid sien. Dit behels dat daar geen primêre ${ }^{51}$ en sekondêre waarhede is nie, terwyl die openbaringsinhoudlyn in sy onderskeie dele tog raakgesien moet word. Dit mag nie gebeur dat enige deel van die openbaringsinhoud geringgeskat word nie, maar dat hierdie onderdele juis hulle regmatige plek kry binne die openbaringsinhoud as geheel. Schilder werk dus nie met hoof- en subtema in die openbaring nie. Vir hom is die openbaring altyd God wat Homself $^{52}$ openbaar. Een enkele tema sou hierdie lading nie dek nie. Hierdie bepaalde openbaringsdoel ${ }^{53}$ is die kennis van God in Christus Jesus.

Hierdie kern in die openbaring, meen Schilder, word deur die Skrif self aangedui. Hy verbind hierdie Godsopenbaringskern ${ }^{54}$ baie nou aan Jesus Christus as die Seun van God. Jesus Christus is die Woord van God deur wie die openbaring geskied. Die Bybel is die Woord wat Skrif geword het,

50 Vgl. Verzamelde werken: Kerk III (1965:263,270).

51 Vgl. Verzamelde werken: Kerk III (1965:260).

52 “...dat God niet maar iets van Zich, maar Zichzelf geopenbaard heeft" (Bij dichters en schriftgeleerden 1927:135).

53 Volgens Schilder:

Oorzover het wel waar is, en dus helemaal niet in strijd met de Schrift, maar niet geopenbaard (want de Schrift zegt een hele massa dingen niet, omdat zij een tendensboek is, dat wil zeggen haar in zichzelf nimmer valse mededelingen richt op een bepaald doel (de kennis Gods in Christus Jezus)... (Verzamelde werken: Kerk III, 1965:270).

54 Volgens Schilder:

... omdat Jezuz en de Bijbel van elkaar houden: Jezus is immers het Woord Gods, dat vleesch geworden is, en de Bijbel is ook het Woord Gods, maar dat Schrift geworden is (Om Woord en kerk I 1948:116; Vgl. ook Om Woord en kerk I 1948:251). 
in samehang met die Woord wat vlees geword het. Hierdie kern ${ }^{55}$ dra dus nie die betekenis van belangrik teenoor minder belangrik nie, maar van die kern wat al hoe breër geopenbaar word. Hierdie radius-gedagte van die openbaring moet volgens Schilder gesien word in die lig van God se voortgaand ${ }^{56}$ openbaring in die geskiedenis, wat weer rus op God se ewige raadsbesluit. Om die eenheid van die Skrif te ontken sou vir hom presies dieselfde wees as om God se handewerk in die geskiedenis ${ }^{57}$ te verloën. Die eenheid van die Skrif, as 'n grondgedagte vir Schilder, is so belangrik dat hy dit in verband bring met die onfeilbaarheid ${ }^{58}$ van Christus self.

\section{SCHILDER KONTRA BARTH}

Vir Schilder is sy siening oor die openbaring in die geskiedenis ononderhandelbaar. Die hele openbaring is vir hom hier op die spel. Hier is ook die groot verskil tussen Schilder en Barth ${ }^{59}$ se openbaringsidee waar te neem.

\section{Volgens Schilder:}

... dat die openbaring in Gods raad is opgenomen en in den tijd zich straks naar Zijn gemaakt bestek meedeelt, voortgaande van kracht tot kracht, van kern tot omtrek, van schemer tot vollen middag toe (Bij dichters en schriftgeleerden 1927:135).

56 Volgens Schilder:

... een voortschrijden der openbaring ... van ommanteling der waarheid "om onzer grovigheid wil" tot ommanteling der waarheid naar haar diepste wezen, naar haar eerst verborgen kern (Bij dichters en schriftgeleerden 1927:401).

57 Volgens Schilder:

... maar zeg niet, dat hij zijn beschouwing over God en Gods werk geen plaats aanwijzen mag in zijn horizontale lijn. In beginsel kom dat neer op de loochening van de eenheid van geschiedenis en eeuwigheid in den raad, het besluit, den wil van God (Bij Dichters en schriftgeleerden 1927:110).

58 “... als wij de eenheid der Schrift loslaten, dan hebben wij de onfeilbaarheid van Christus ook verloren"(Om Woord en kerk III 1951:95).

59 Volgens Schilder:

En nu zegt Barth, gebruik makende van een meer handige, dan ernstige woordspeling: "definitie" betekent eigenlijk "begrenzing" of "beperking". Terwijl de kerk dus de waarheid, die geopenbaard is, "definieert", beperkt ze haar; in de dogma's (meervoud) beperkt zij de geopenbaarde waarheid, het Woord van God (dat onbereikbaar, ongrijpbaar, ondefiniëerbaar is). Maar op die manier maakt de kerk van Gods Woord een menschenwoord. Gods Woord en het dogma, ge vraagt, hoe die twee tot elkaar staan? Gelijk de hemel is boven de aarde, zò is Gods Woord boven het dogma (Verzamelde werken: Kerk II 1962:331). 
Waar Barth die openbaring in onvoltooide teenwoordige sin verstaan, sien Schilder dit op sy beurt weer as beide voltooid teenwoordig ${ }^{60}$ en onvoltooid teenwoordig. Die openbaring is dus vir hom beide gebeure en historiese gebeurtenis. Openbaring word vir hom inderwaarheid geopenbaardheid, vir Barth nie. Schilder sien die Skrif nie maar bloot as 'n herinnering en verwagting van hierdie momentele gebeurtenis nie. As die Skrif bloot as getuienis $^{61}$ van die Woord van God gesien word en nie as die Woord van God self nie, dan is effektiewelik die gesag van die Woord prysgegee. Schilder sien dus nie soos Barth die openbaring identies met versoening nie. Vir Schilder gaan die openbaring ook oor versoening, maar mag nie daarmee geïdentifiseer ${ }^{62}$ word nie, aangesien die verdoemenis ook verkondig word. Hier sien Schilder dat Barth die grens tussen die kerk en die wêreld ophef.

\section{ONTWIKKELING VAN OPENBARING}

Die openbaring is vir Schilder eenlynig, van bo na onder. Die openbaring dra 'n gedateerde ${ }^{63}$ eenmalige karakter. Hierdie gedateerde openbaring vertoon drie ekklesiologiese momente, naamlik:

- Openbaring aan die mens waar die lyn regdeur die kerk loop. Hier is nie noodwendig geloofsontvanklikheid betrokke nie.

- Openbaring in die mens wanneer die Heilige Gees die openbaring gelowig laat ontvang.

- Openbaring deur die kerk wanneer God in die kerk se gehoorsaamheid geopenbaar word.

Die openbaring het ook vir hom 'n voortgaande en meegaande karakter. Hierdie dinamiese element is deurvleg in Schilder se teologie. Schilder sien die mens as verbondswese. Alhoewel hy die mens as medearbeider van God sien wat deur verbondsgehoorsaamheid Christus moet volg, is hy redelik konsekwent in sy siening dat die mens juis vanweë hierdie verbondsvoorreg nie gesien moet word as mede-openbaarder nie.

60 Volgens Schilder:

... we geloven, dat God zich openbaart in den onvoltooid tegenwoordigen, doch ook dat Hij zich geopenbaard HEEFT in den voltooid tegenwoordigen tijd (Verzamelde werken: Kerk III 1965:167).

61 Vgl. Verzamelde werken: Kerk III (1965:282).

62 Vgl. Heidelbergsche Catechismus I (1947:509-510), Heidelbergsche Catechismus II (1949:74-75).

63 Vgl. Om Woord en kerk I (1948:266). 
Tog is Schilder oop vir kritiek op hierdie punt. Die vraag ontstaan wat die gevolg kan wees as die voortgaande karakter oorbeklemtoon word. Kan die eenlynigheid nie in gedrang kom nie? Schilder handaaf die verbond in al sy skakerings, en dat die mens aktiewe ontvanger en nie medesamesteller van die openbaring is nie. Daar moet egter gevra word of Schilder met sy siening oor die vrye lied, ${ }^{64}$ konsekwent bly aan sy eie grondgedagtes; dit terwyl hy baie streng maatstawe vir psalmberymings het.

Die meegaande ${ }^{65}$ karakter van die openbaring is daarin geleë dat God se teenwoordigheid met die kerk as openbaringsadres meegaan. Hierdie aspek word verbind met 'n ander grondgedagte in Schilder se denke, naamlik die onbeweeglike ${ }^{66}$ koninkryk van God. Dit kom kortliks daarop neer dat God met sy kerk, en trouens alle dinge, bewegend onderweg is. Hierdie beweging van die kerk, die meegaande karakter van die openbaring se doel is die koms van die onbeweeglike koninkryk waar God alles in almal sal wees.

Verder beskou hy die openbaring ook as eenmalig, van voor na agter. Dit is waar eskatologie en protologie wedersyds op mekaar betrek word. Hierdie teruggryp ${ }^{67}$ na die begin, en die vooruitgryp na die einde, is ' $n$ belangrike tema vir Schilder. Die begin kan nie sonder die einde verstaan word nie. So handhaaf hy dat God se skeppingsbedoeling as protologie nie deur die eskatologie verslind word nie, maar juis sy volmaakte uiteinde vind. Die vashou van beide hierdie kante is belangrik aangesien die eenheid in die openbaring vereis dat vir beide plek gegee sal word.

Alhoewel die protologie die eskatologie oproep, is daar tog 'n deurlopende verdieping. Die openbaringsbedelings vertoon dus ook 'n spesifieke "klein-na-groot" karakter. Hy sê God se aandseëning ${ }^{68}$ is meer as sy oggendgroet, sy omega is voller as sy alfa waarmee Hy die onderwysing begin. Die lyn is egter nooit van onwaar na waar nie, maar van dowwer lig na helderder lig. Hierdie "groter-aan-die-einde" bring groter verbondsverpligtinge op die mens. Hoe meer openbaring, hoe noukeuriger moet die gehoorsaamheid wees.

Aangesien Schilder uitgaan van die eenheid van God self, en hy daarom die openbaring ook as 'n eenheid sien, volg dit logies dat die gesag van die

64 Vgl. Smelik (2003:61 e.v., 66); De Reformatie (xxiii, 327).

$65 \mathrm{Vgl}$. Om Woord en kerk I (1948:84).

66 Vg. Om Woord en kerk I (1948:94-95).

67 "Zij doet, gelijk Christus in de bergrede en in andere redevoeringen deed: teruggrijpen naar het begin" (Verzamelde werken: Kerk II 1962:86).

68 Vgl. Om Woord en kerk I (1948:250). 
Woordopenbaring vir hom een en dieselfde is as Christus ${ }^{69}$ se gesag. Wie dus die band aan die Heilige Skrif vashou, wie gehoorsaam reageer op die openbaring, is tegelykertyd besig om onder die gesag van Christus se heerskappy te buig. Dit is dus ook duidelik waarom Schilder voorrang verleen aan die Woordgesag bo die geskiedenis. Die eenheid van die geskiedenis vind hy ook in die eenheid van die Woordopenbaring en dié se geskiedenis.

\section{SCHILDER SE WAARDE OP TWEE FRONTE}

Schilder se openbaringsleer is inderdaad die hele fondament waarop sy teologie berus, en waarvoor hy so hard in sy lewe geveg het. Sonder die openbaring sou daar geen teologie en geen kerk meer moontlik wees nie. Schilder was sy tyd ver vooruit. Hy wys duidelik aan dat die openbaring op twee fronte in die christendom dreig om verswelg te word. Aan die een kant is daar immer die gevaar van die mistisisme wat die Woord altyd by nabaat wil bysleep om dit wat die menslike hart, sonder en los van die openbaring, bedink het, te kamoefleer as goddelike wil.

Verder het Schilder aangetoon dat die afgee van die eenheid van die openbaring inderdaad die afgee is van die grens tussen die kerk en die wêreld, omdat die belydenis oor die eenheid van God dan prinsipieel prysgegee is. Waar die openbaring nie christologies-pneumatologies benader word nie, dreig die kerk inderdaad om sagkens deur die mistiek in die wêreld opgelos te word.

Schilder se openbaringsleer, wat geheel en al sy ekklesiologie bepaal, los ons voor die tergende vraag: bepaal hermeneutiek, ook in al sy buitebybelse skakerings, wat die kerk gaan wees of bepaal die ware kerk wat geldige hermeneutiek is? Hiervoor is dit nodig dat kennis geneem word van Schilder se aandrang op die primaat van die Woordopenbaring. Die implikasie is dat die verstaan van die goddelike openbarings-Woord die verstaan van die menslike woord bepaal. Dit het geweldige groot gevolge vir die taalteorie, veral deesdae waar die teologie bykans geheel en al hermeneutiek geword het. Miskien het Schilder die fakkel wat die teologie van hierdie eeu van totale hernemeutiese inploffing kan red, op die berg neergesit. Wie oor die openbaring van God wil praat, sal ook oor die ware kerk moet praat. Dit het tyd geword om die post-modernisme die rug toe te keer.

Die post-modernisme, wat Schilder nie geken het nie, maar profeties as "tussen ja en nee" benoem het, mag nie weer vervang word met ou of nuwe fundamentalisme nie. Schilder se openbaringsleer, en dan veral die dinamiese 
element daarin, waarsku tydig teen die stolling wat die fundamentalisme teweeg wil bring. Hierdie stolling van die kerk, waar die kerk onbeweeglik word aangesien die meegaande karakter van die openbaring ontken word, vind deesdae veral plaas in die hantering van metafore los van hierdie openbaringsgegewe.

Wat Schilder sê oor die verskillende openbaringsbedelings is opnuut aktueel. Hierin lê ook die groot gevaar van 'n fundamentalistiese hantering van metafore, naamlik dat sekere metafore ongemotiveerd voorkeuraandag bo ander kry en dat die fundamentalistiese hantering van metafore nie die openbaringsgang herken of erken nie, en uiteindelik die openbaringskern laat verdring deur wettisisme, waar op grond van kwasi-waarheidsaansprake teruggegryp ${ }^{70}$ word na vorige openbaringsbedelings, sonder om die kernpuntverskuiwing ${ }^{71}$ in gedagte te hou.

70 Vgl. hiervoor byvoorbeeld Opperman (2004:9-24) waar die metafoor "huis van God" fundamentalisties hanteer word deurdat die voortgaande openbaring gestol word in die patriargale huisgesin. Vanaf die tempel word beweeg na die huisgesin as openbaring van die heerlikheid van God:

Een van die kenmerke van die boek Handelinge is die spanning tussen tempel en huis(gesin). Die Christelike huis neem gaandeweg in Handelinge in belangrikheid toe ten koste van die tempel as historiese instelling. In dié verband dien die huis(gesin) as beide 'n historiese en heilshistoriese werklikheid. Histories in die sin dat die tempel as plek van die samekoms en aanbidding algaande deur die huis(gesin) vervang is. Die tempeldeure is immers uiteindelik deur die Jode self gesluit. (Hand. 21:30). Heilshistories in die sin dat die tempel uiteindelik deur die huis van Dawid vervang sou word (2 Sam. 7) soos dit inderdaad in Jesus Christus gebeur het. In die proses beweeg ook die Gees van God en sy heiligmakende krag van die tempel na die Christelike huis(gesin) (Opperman 2004:15.)

Dit staan in skrille kontras met Schilder se openbaringsleer wat die Skrifgetuienis weergee dat die heerlikheid van God in die tempel, deur die inwoning van die Gees van Christus, oorgegaan het na die Nuwe-Testamentiese gemeente. Opperman se fundamentalisme ruk die patriargale huis de-histories terug in die plek van die ware huis van God, die christelike gemeente. Opperman se siening moet, as dit konsekwent deurgevoer word, tot ontkerking lei. Gemeente word vervang met huiskerk, waarin die patriarg as bedienaar voorgaan. Hierdie stolling van die metafoor verraai die inherente natuur-teologie waarop hierdie fundamentalisme geskoei is, aangesien die huisgesinopset voorwaarde word vir die bediening en ontvangs van die Woordopenbaring. Indien Schilder se standpunt oor die kernpunt van die openbaring aanvaar word, het die fundamentalistiese uitgangspunt inderdaad weinig met die gereformeerde leer te doen.

71 “...omdat de heerlijkheid van Jeruzalems steenen tempel is overgegaan op de gemeente van het Nieuwe Testament" (Om Woord en Kerk I 1948:124). 
Schilder se openbaringsleer bied aan die ware kerk 'n skerp swaard om weer op twee fronte te veg: teen die mistisisme en teen die fundamentalisme. Inderdaad bepaal die openbaring die kerk. Wie die Woord vervaag (mistiek) of vertraag (fundamentalisme), skaad die liggaam van Christus. Die troos is dat die Woord lewend is en lewe gee. Waar die openbaring, soos Schilder bely, christologies-pneumatologies benader word, daar gloei die gloed van die Pinkstervuur ${ }^{72}$ steeds:

Waar die vuur is, die warmte, daar is die lig ook, die kennis.

\section{BIBLIOGRAFIE}

\section{BERKOUWER G C}

1989. Zoeken en vinden. Herinnering en ervaringen. Kampen: Kok.

DE JONG J

1995. Schilder on revelation. In: J. Geertsema (ed.), Always obedient — essays on the teachings of $d r$. Klaas Schilder. Phillipsburg: P\&R Publishing.

\section{OPPERMAN G}

2004. Die huis van God. In: S. le Cornu (red.), Ons gedrag in die huis van God. Esra Verslag 49:9-24.

\section{SCHILDER K}

1926. Licht in den rook. Delft: Meinema.

1927. Bij dichters en schriftgeleerden. Amsterdam: Uitgeversmaatschappij Holland. 1929. Tusschen 'ja' en 'neen'. Kampen: Kok.

1933. Zur Begriffsgeschichte des "Paradoxon". Mit besonderer Berïcksichtigung Calvins und des nach-kierkegaardschen "Paradoxon". Kampen: Kok.

1947. Heidelbergsche Catechismus. Zondag 1-4. Deel I. Goes: Oosterbaan \& Le Cointre.

1948. Om Woord en kerk. Preeken, lezingen, studiën en kerkbode artikelen. Deel I. Goes: Oosterbaan \& Le Cointre.

72 "Waar het vuur is, de warmte, daar is ook het licht, de kennis" (Om Woord en Kerk III 1951:40). 
1949a. Om Woord en kerk. Preeken, lezingen, studiën en kerkbode artikelen. Deel II. Goes: Oosterbaan \& Le Cointre.

1949b. Heidelbergsche Catechismus. Zondag 5-7. Deel II. Goes: Oosterbaan \& Le Cointre.

1950. Heidelbergsche Catechismus. Zondag 8-9. Deel III. Goes: Oosterbaan \& Le Cointre.

1951a. Heidelbergsche Catechismus. Zondag 10. Deel IV. Goes: Oosterbaan \& Le Cointre.

1951b. Om Woord en kerk. Preeken, lezingen, studiën en kerkbode artikelen. Deel III. Goes: Oosterbaan \& Le Cointre.

1953. Om Woord en kerk. Preeken, lezingen, studiën en kerkbode artikelen. Deel IV. Goes: Oosterbaan \& Le Cointre.

1960. Verzamelde werken. Afdeling 3. De kerk, Deel I. Goes: Oosterbaan \& Le Cointre.

1962. Verzamelde werken. Afdeling 3. De kerk, Deel II. Goes: Oosterbaan \& Le Cointre.

1965. Verzamelde werken. Afdeling 3. De kerk, Deel III. Goes: Oosterbaan \& Le Cointre.

1977. Christus in zijn lijden. Overwegingen van het lijdensevangelie. Christus aan den ingang van zijn lijden. Deel I. Kampen: Kok.

\section{SMELIK J}

2003. Schilder, de kerkdienst en het kerklied. In: G. Harinck (red.), Alles of niets. Opstellen over K. Schilder. AD Chartas-reeks 6. Barneveld: De Vuurbaak.

$\begin{array}{ll}\text { Trefwoorde } & \text { Keywords } \\ \text { Schilder } & \text { Schilder } \\ \text { Openbaring } & \text { Revelation } \\ \text { Skrifgesag } & \text { Authority of Scripture } \\ \text { Antropomorfisme } & \text { Anthropomorphism } \\ \text { Hermeneutiek } & \text { Hermeneutics } \\ \text { Geskiedenis } & \text { History } \\ \text { Barth } & \text { Barth } \\ \text { Mistisisme } & \text { Mysticism } \\ \text { Fundamentalisme } & \text { Fundamentalism }\end{array}$

